\title{
Review Article \\ Experiments Are Revealing a Foundation Species: A Case Study of Eastern Hemlock (Tsuga canadensis)
}

\author{
Aaron M. Ellison \\ Harvard Forest, Harvard University, 324 North Main Street, Petersham, MA 01366, USA \\ Correspondence should be addressed to Aaron M. Ellison; aellison@fas.harvard.edu
}

Received 27 April 2014; Accepted 28 June 2014; Published 17 July 2014

Academic Editor: Alistair Bishop

Copyright (C) 2014 Aaron M. Ellison. This is an open access article distributed under the Creative Commons Attribution License, which permits unrestricted use, distribution, and reproduction in any medium, provided the original work is properly cited.

Foundation species are species that create and define particular ecosystems; control in large measure the distribution and abundance of associated flora and fauna; and modulate core ecosystem processes, such as energy flux and biogeochemical cycles. However, whether a particular species plays a foundational role in a system is not simply asserted. Rather, it is a hypothesis to be tested, and such tests are best done with large-scale, long-term manipulative experiments. The utility of such experiments is illustrated through a review of the Harvard Forest Hemlock Removal Experiment (HF-HeRE), a multidecadal, multihectare experiment designed to test the foundational role of eastern hemlock, Tsuga canadensis, in eastern North American forests. Experimental removal of T. canadensis has revealed that after 10 years, this species has pronounced, long-term effects on associated flora and fauna, but shorter-term effects on energy flux and nutrient cycles. We hypothesize that on century-long scales, slower changes in soil microbial associates will further alter ecosystem processes in T. canadensis stands. HF-HeRE may indeed continue for $>100$ years, but at such time scales, episodic disturbances and changes in regional climate and land cover can be expected to interact in novel ways with these forests and their foundation species.

\section{Introduction}

A decade ago, my colleagues and I introduced the concept of a foundation species (sensu Dayton [1]) to terrestrial ecologists [2]. At the time, we were focused on the potential for certain tree species to act as foundation species, species that create and define particular ecosystems; control in large measure the distribution and abundance of associated flora and fauna; and modulate core ecosystem processes, including energy flux and biogeochemical cycles [2]. We asserted that the possession of all three of these characteristics distinguish foundation species from other "important" species, such as keystone predators, core species, dominant species, cornerstone species, and ecosystem engineers ([2] and see below). Although we identified a number of different tree species that we hypothesized were good candidates for foundation species, at the time, many of the participants in the workshop that contributed to [2] were focused on a particular species, Tsuga canadensis (L.) Carr., for which decades of observational data (summarized in [3]) had suggested that it possesses the three characteristics associated with a foundation tree species.

First, T. canadensis is widespread and abundant. Its range in eastern North America spans more than $10,000 \mathrm{~km}^{2}$ from north of Georgia into southern Canada and west into Michigan and Wisconsin (Figure 1). In the cove forests in the southern Appalachian Mountains, in the mixed coniferhardwood forests of New England and along riparian corridors throughout its entire range, $T$. canadensis can comprise $>50 \%$ of the total basal area in a given stand $[4,5]$. Second, it has unique assemblages of associated fauna: particular birds, arthropods, and salamanders that live in the T. canadensis understory or among its evergreen branches [6-12]. Specialist communities of aquatic invertebrates and fish inhabit streams that flow through T. canadensis stands $[13,14]$.

Finally, ecosystem dynamics in T. canadensis stands differ from surrounding stands of hardwoods or other conifers. The dense canopy of mature T. canadensis allows little light to penetrate the forest floor and the soils beneath this tree are quite cool [15]. The evergreen canopy photosynthesizes whenever 


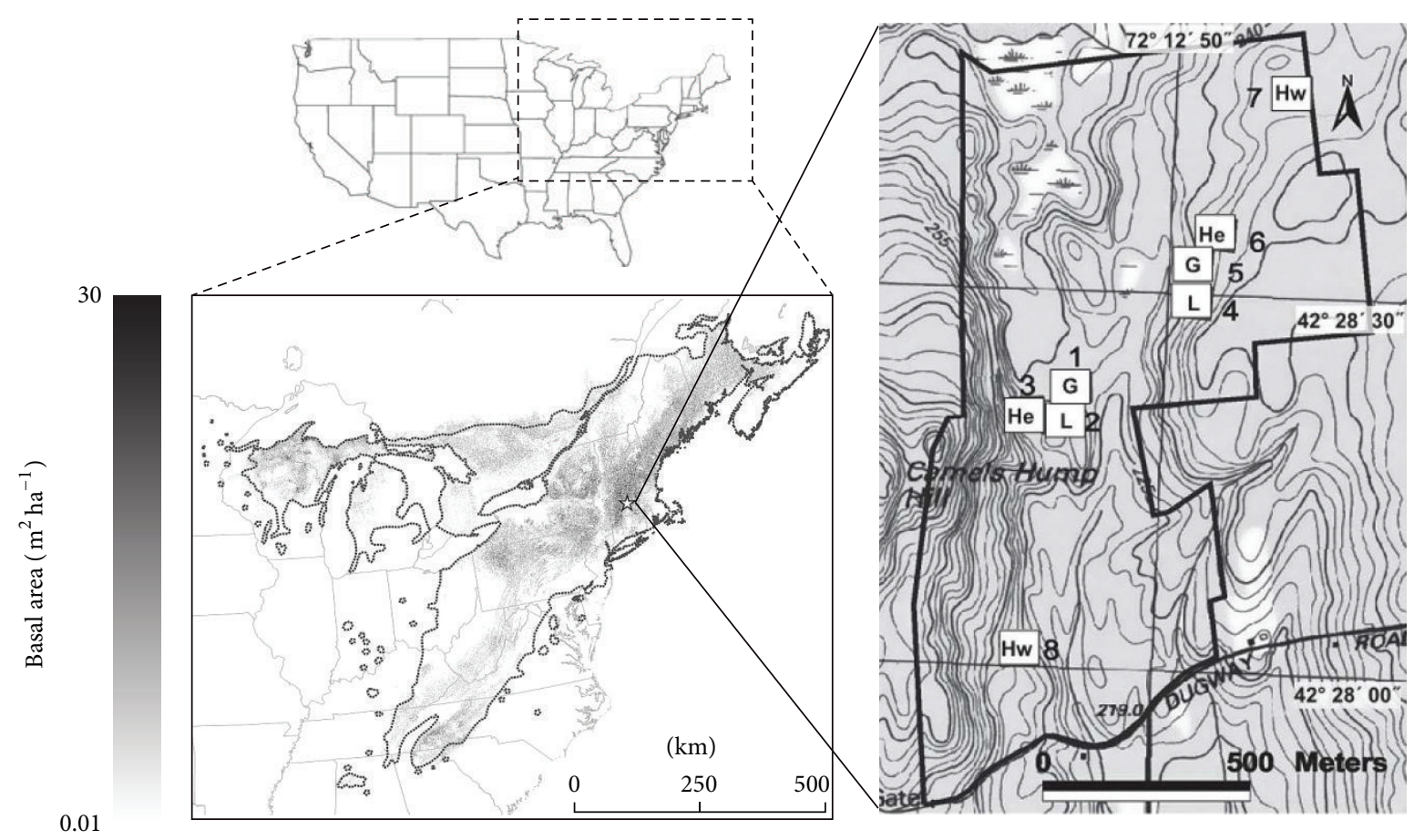

Hemlock range

FIgURE 1: Distribution (grey shading indicating basal area in $\mathrm{m}^{2} / \mathrm{ha}$ ) of Tsuga canadensis in northeastern North America; location of the Harvard Forest (star in regional map at lower left); and layout of the Harvard Forest Hemlock Removal Experiment. In the right-hand panel, the treatments applied to each 0.81-ha plot are as follows: He: unmanipulated hemlock control; Hw: unmanipulated hardwood control; G: bark and cambium of all hemlock seedlings, saplings, and trees girdled with chainsaws and knives; L: all merchantable hemlock ( $\geq 20 \mathrm{~cm}$ diameter at breast height $[\mathrm{DBH}]$ ) and some merchantable hardwoods and white pines (Pinus strobus) cut and removed from the site.

air temperatures are above freezing, but photosynthetic rates are slow, water-use efficiency is high, and peak carbon fixation by $T$. canadensis occurs in spring and fall, not in the summer when cooccurring broadleaved, deciduous trees are in full leaf [16]. Because the needles of T. canadensis are slower to decompose than all of the other regionally cooccurring trees [17], organic matter accumulates unusually rapidly beneath $T$. canadensis canopies [18], but the soils are acidic and nutrientpoor [19]. Overall, both carbon flux [16, 20-23] and nutrient cycling [19, 24-26] are much slower in T. canadensis stands than in stands dominated either by hardwoods or other conifers.

All of these characteristics fit our notion of how a foundation species should differ from other cooccurring species, but I emphasize that the idea that $T$. canadensis is a foundation species was presented in 2005 as a hypothesis to be tested ([2]; see also [27-29]), not as a foregone conclusion. In this review paper, I illustrate the importance of using large-scale field experiments to provide a critical test of this hypothesis.

\section{A Natural Experiment}

In the central and southeastern portion of its range-from southern Vermont, New Hampshire, and Maine south to Georgia-T. canadensis is dying from infestations by a nonnative insect, the hemlock woolly adelgid (Adelges tsugae
Annand). This insect was introduced into the United States from Japan in the early 1950s [30]. Since its initial introduction near Richmond, Virginia, the hemlock woolly adelgid has spread primarily northeast and southwest, but it crossed over to the western side of the Appalachian Mountains sometime in the late 1990s or early 2000s [31-33]. Tsuga canadensis has little, if any, resistance to the hemlock woolly adelgid [34] and rarely recovers from chronic infestations $[35,36]$. In many infested stands, $>90 \%$ of $T$. canadensis dies within 10 years of the arrival of the adelgid [37-39].

Detailed longitudinal studies of T. canadensis decline have been underway in southern New England since the adelgid first colonized the region in the 1980s. An expectation of the imminent, rapid death of T. canadensis [40] and the subsequent transformation of the forested landscape into early successional habitat, as the adelgid swept through and living trees were preemptively salvaged by landowners intent on extracting economic value from their forests [37, $41,42]$, led to the establishment of a network of permanent monitoring plots in Connecticut and Massachusetts in the 1990s [36, 37, 43]. Two decades later, data from this permanent plot network have shown that in Connecticut, where T. canadensis is distributed patchily in relatively small stands, tree mortality has been somewhat slower than initially forecasted and salvage logging has been less extensive than feared [36]. Faunal change in these small declining stands 


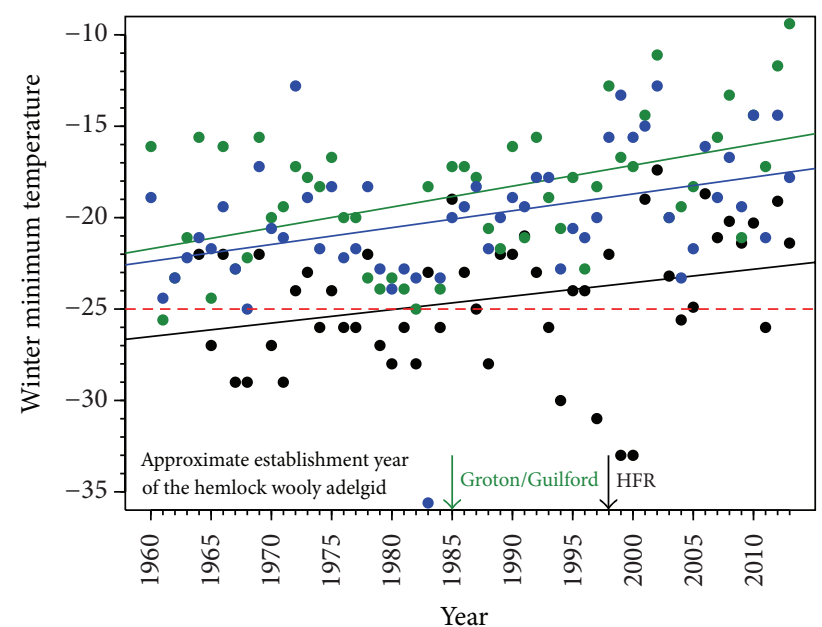

FIgURE 2: Winter minimum temperatures (1960-2013) at Groton, Connecticut $\left(41.35^{\circ} \mathrm{N},-72.03^{\circ} \mathrm{W}\right.$; green symbols), Storrs, Connecticut $\left(41.81^{\circ} \mathrm{N},-72.25^{\circ} \mathrm{W}\right.$; blue symbols), and Harvard Forest (HFR; black symbols) $\left(42.53^{\circ} \mathrm{N},-72.19^{\circ} \mathrm{W}\right)$ along with approximate establishment dates of the hemlock woolly adelgid (Adelges tsugae) in southern Connecticut and at Harvard Forest (green and black arrows). Solid lines are best-fit linear temperature trends; the dashed red line at $-25^{\circ} \mathrm{C}$ indicates the $\mathrm{LT}_{50}$ for the hemlock woolly adelgidthe temperature at which $50 \%$ mortality of the adelgid is expected $[46,47]$.

has been pronounced (e.g., $[6,7])$ but carbon storage-one measure of ecosystem function-has proven to be resilient to conversion of $T$. canadensis-dominated stands to early successional hardwoods (Betula lenta L., Acer rubrum L.). Both models [44] and observations [45] suggest that the distribution, but not the magnitude, of carbon storage is changed across the landscape as $T$. canadensis declines and disappears.

As the adelgid continues to move north, however, it has arrived in a region where T. canadensis is more abundant, and dispersal between stands is easier [32,33]. Climate, especially winter minimum temperature, remains the primary environmental factor limiting the northward spread (Figure 2; see also [31, 45]), overwinter survivorship, and long-term persistence of the hemlock woolly adelgid [36, 46-50].

Although the most recent winter (2013-2014) was unusually cold relative to the last 30 years, the minimum temperature at Harvard Forest, in north-central Massachusetts still did not drop below $-20^{\circ} \mathrm{C}$; the last time the temperature at Harvard Forest fell below $-25^{\circ} \mathrm{C}$ was on a single day in January 2011, and before that on three successive January nights in in 2004 [51] (Figure 2). The expectation is that T. canadensis will continue to decline relatively rapidly throughout the region, except in colder, high elevation sites, such as in the Adirondack Mountains of New York [36].

In sum, observational studies have lent some support to the hypothesis that T. canadensis is a foundation species in eastern US forests. Where it is abundant, T. canadensis acts as a structural species (sensu Huston [52]), creating and defining "hemlock forests" that are recognized not only by ecologists but also by poets, writers, naturalists, and many other nonscientists [3, 27]. Tsuga canadensis also supports unique assemblages of associated organisms, and the most pronounced ecological changes observed following loss of T. canadensis have been observed in plant and animal assemblages. The diversity and abundance of understory herbs, shrubs, and saplings and of birds, salamanders, fish, and invertebrates changes quickly-hemlock specialists disappear and are replaced by more common inhabitants of second-growth hardwood forests-and these changes persist for decades. In many cases, the local (stand-level) species richness increases following $T$. canadensis loss, but the regional ("beta") diversity declines as the forested landscape becomes more homogeneous. Fewer long-term (years-todecades) change in ecosystem processes have been observed after T. canadensis dies. As hardwoods regrow rapidly, energy and nutrient cycles are restored [19]. Soil characteristics certainly differ between hemlock and hardwood forests. Thus, very long-term (i.e., century-scale) monitoring will be required to determine how soil properties may be changed following loss of $T$. canadensis and how (or even if) these potential changes will affect faunal diversity and ecosystem processes.

\section{The Need for Manipulative Experiments}

Observational studies and manipulative experiments are complementary. Long-term observational studies like the ones described above have documented changes occurring in hemlock forests throughout eastern North America, not only their current decline but also their historical and prehistorical (paleoecological) decline and subsequent recovery (e.g., [5355]). Such observations have been critical both for developing models of possible future conditions of eastern forests and for testing the accuracy of these models when "hind-casting" past conditions (e.g., [56]). These observations and models also have been used to suggest best practices for local and regional forest management in the face of imminent decline of T. canadensis (e.g., [57]). But there is little control over the timing and location of observational studies. For example, scientists could not decide when the adelgid colonized a stand, when a logging crew showed up, or compare these "natural" events to various types of forest management on more-or-less equivalent sites at the same time.

Large field experiments address these logistical challenges and improve the strength of the inferences made about how forests respond to loss of $T$. canadensis. Although observational studies have come to dominate large-scale ecological research in recent decades (e.g., [58-60]), it is worth remembering that experiments remain the "goldstandard" for scientific hypothesis testing. Well-designed experiments rapidly identify spurious correlations while reliably identifying cause-and-effect relationships (e.g., [61-64]). Although large-scale field experiments still must account for environmental heterogeneity (e.g., through blocking; [65]), selecting comparable sites where contrasting treatments are applied and untreated "controls" are sited can provide robust power to test hypotheses. In forest stands, collection of extensive data on a wide range of variables and processes 
before the stand is manipulated (i.e., the use of a beforeafter-control-impact [BACI] design) further accounts for underlying temporal variability while, under appropriate conditions, minimizing temporal pseudoreplication [66, 67]. Finally, when manipulations are applied, the timing, type, and intensity can be specified more precisely.

Ecologists have always looked to manipulative experiments to provide strong and convincing evidence that particular species play disproportionate roles in ecological systems. Paine [68] used removal experiments and exclosures to identify keystone predators - those species enhance species diversity of organisms at lower trophic levels by preferentially preying on competitive dominants. Hanski [69] defined core species to be species that are locally abundant and regionally common; he contrasted them with associated satellite species that are sparse or rare (sensu Rabinowitz [70]). Hanski [69] went on to elaborate the core-satellite hypothesis and derived a metapopulation model to explain relationships between the local abundance of an individual species and its distribution on the broader landscape. This hypothesis and the model have been examined extensively in many systems [71], but manipulative experiments testing the coresatellite hypothesis are comparatively uncommon (recent examples include $[72,73]$ ). Numerous other hypotheses, none of which have unequivocal (experimental) support, have been proposed to explain observed distributions of common and rare species [74]. Grime [75] characterized dominant species that competitively exclude subordinate species by garnering a disproportionate share of resources and contributing most of them to productivity; many subsequent studies in grasslands have provided experimental support for the functional importance of dominant species in maintaining ecosystem functioning (e.g., [76-78]) and the conservation relevance of dominant species [79].

Holling [80] elaborated on Paine's definition of a keystone species by hypothesizing that all terrestrial ecosystems are controlled and organized by a small set of "extended keystone" species that share the characteristics of core species, dominant species, and keystone predators. Although the idea of extended keystone species is enticing (and as of April 2014 according to ISI/Web of Science, Holling [80] has been cited nearly 800 times), it is difficult to see how a single species could have characteristics of both keystone predators, which either are uncommon or account for only a small fraction of the biomass in an assemblage, and dominant species that are common and make up most of the biomass in an ecosystem. For example, in the benthic ecosystem at McMurdo Sound, Antarctica, that Dayton [1] was studying when he developed the foundation species concept, the sponge Mycale acerata Kirkpatrick was the competitive dominant but normally was rare because it was eaten by a specialized predatory sea-star, Perknaster fuscus antarcticus (Koehler), another example of keystone predation. In contrast, a group of sponges in the family Rosellidae accounted for the majority of the biomass and the physical structure of the benthic environment at McMurdo Sound $[1,81]$ and these foundation species defined the benthic assemblages. It is not clear that any of these taxa would qualify as extended keystone species.
In the mid-1990s, the idea that particular species can create physical structures in the environment, limit or amplify variation in environmental conditions, or provide resources or habitats for other species was independently proposed by Huston [52], who termed such species structural species and Jones et al. [82] who called them ecosystem engineers. In the last two decades, hundreds of experimental studies have been used to unravel the effects of ecosystem engineers.

As virtually all species modify their environment to some degree (the process of niche construction-[83]), Ellison et al. [2] emphasized that the effects of foundation species on cooccurring species and their environments should be disproportionate to their abundance or biomass, and their actions should occur from within (as by autogenic ecosystem engineers of [82]), not from without (as by allogenic ecosystem engineers of [82]). But with few exceptions, the key difference between ecosystem engineers and foundation species is their abundance. Autogenic ecosystem engineers, like cornerstone species [84], often are uncommon or rare and exert strong "bottom-up" effects on higher trophic levels. Exceptions are species like cordgrass (Spartina species; e.g., [85-88]) and some invasive plants (e.g., [89, 90]). Like these autogenic engineers, foundation tree species should be common and exert strong bottom-up effects [91].

\section{The Harvard Forest Hemlock Removal Experiment}

To determine experimentally the level of support for our hypothesis that T. canadensis is a foundation species my colleagues and I have used hectare-scale manipulations at Harvard Forest in Massachusetts. The Harvard Forest Hemlock Removal Experiment (HF-HeRE; [92]) is a multihectare, decades-long BACI experiment that complements the regional survey of $T$. canadensis described above. HFHeRE has overcome many of the logistical and inferential challenges of studying system-wide consequences of loss of this species and has allowed for more focused, yet comprehensive, testing of the hypothesis that T. canadensis is a foundation species (Figure 3).

Forest blocks in HF-HeRE includes two removal treatments each applied to $\approx 90 \times 90-\mathrm{m}(0.81-$ ha $)$ forested plots (map in Figure 1, above): girdling of all T. canadensis individuals to simulate the progressive death-in-place of trees caused by the adelgid and logging all T. canadensis individuals $>20 \mathrm{~cm}$ diameter, along with some additional merchantable trees, to simulate a typically intensive level of preemptive salvage harvesting [92]. These canopy-manipulation treatments were paired with a hemlock control in which no manipulation occurred and a hardwood control dominated by B. lenta and A. rubrum what is expected to be the future conditions of most current T. canadensis stands in (north)eastern North America [26, 44, 92].

Researchers working on HF-HeRE have studied a wide range of responses to the experimental treatments. These studies have included changes in microclimate [15]; turnover and succession of plants in the seed bank [93, 94]; shifts in composition and abundance of understory and overstory plants [19]; dynamics of fauna including invertebrates [12], 


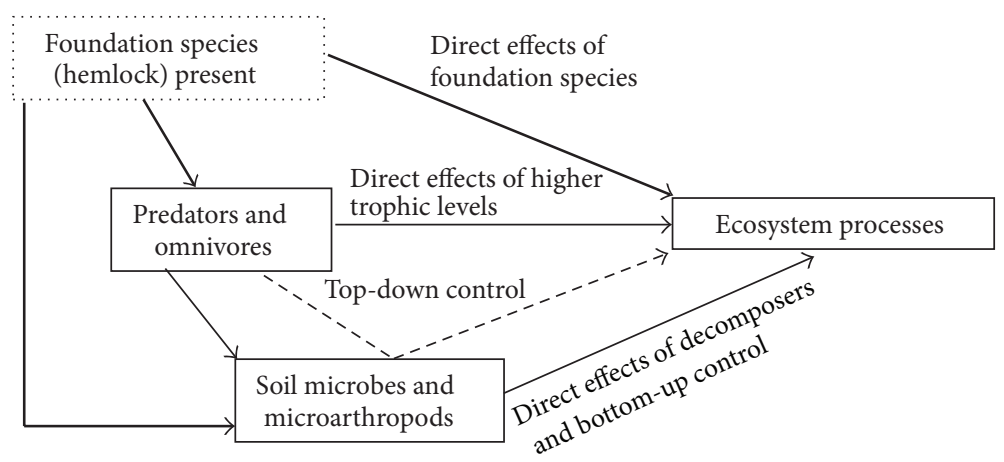

(a)

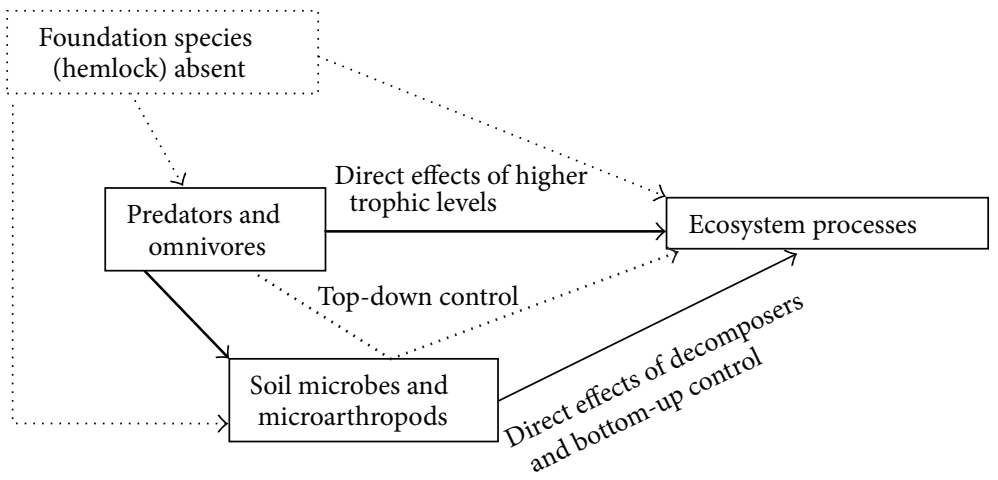

(b)

FIGURE 3: Conceptual model illustrating the effects of experimentally removing a foundation species from a forested ecosystem. Line width indicates the strength of influence of the foundation species on ecological processes within the forest; dotted lines indicate indirect effects. Redrawn and modified from [92].

salamanders [9], small rodents (A. Degrassi, unpublished data), white-tailed deer (Odocoileus virginianus Miller), and moose (Alces alces (L.)) (E. Faison, unpublished data); and fluxes and cycles of nitrogen and carbon [19, 45, 95]. All of these changes reflect the relative influence of T. canadensis, the adelgid, human activities past and present, and background variability inherent in any ecological system. Disentangling these influences and interpreting our experimental results have been informed not only by region-wide observations discussed above but also by a deep knowledge of the experimental site itself and its history [96], as well as by extensive observational information about how changes in abundance and distribution of $T$. canadensis distribution, past and present, have altered forests across New England.

When HF-HeRE was established in 2003, the adelgid had not yet reached far into the Harvard Forest; the 1998 colonization event (Figure 2) was confined to a single tree adjacent to the main administration and office building and was thought to have been brought there on the clothing of a researcher. But in 2003, we expected the adelgid to expand into the forest at some point in the near future; in the interim, the experiment was designed to examine the physical loss of $T$. canadensis killed in place (from girdling) to physical loss and removal of this species (from logging) [92]. We first observed the adelgid at low densities in all of the control plots and on remaining T. canadensis throughout the experimental plots in 2009 and 2010. Since then, the focus of the experiment has changed from one in which we contrasted the effect of girdling and salvage logging to one in which we now contrast the effects of physical loss of T. canadensis (from girdling) to the effects of mortality due to the adelgid (see also [25]).

4.1. Forest Microclimate. Most of the early responses of the forest to our treatments were consistent with our hypothesis that $T$. canadensis was functioning as a foundation species in these forests. Forests dominated by $T$. canadensis are dark, cool, and moist, but after girdling or logging they became bright, warm, and dry [15]. These changes occurred more rapidly in the logged plots than in the girdled plots, but by 2009 , the microclimates in plots subject to these two different canopy-manipulation treatments nearly had converged. Removing the $T$. canadensis canopy also changed the daily and seasonal variance in microclimate. Air temperatures in the logged and girdled plots tended to be warmer during the day and cooler during the night and warmer during the summer and colder during the winter than air temperatures in either intact hemlock or hardwood control plots. The daily and seasonal extremes were more pronounced early on in the logged plots, but five years after the treatments had been applied, the variability was similar in both logged and girdled plots. The observed changes in microclimate and 
canopy cover, induced either by the adelgid or by preemptive salvage logging, appeared to have induced a cascade of effects on forest dynamics that began with altered vegetation composition, continued through the animals, and ended in the cycling of nutrients and energy (Figure 3).

4.2. Seed Bank and Seed Rain. Posttreatment seed rain was dominated by Betula spp. seeds, with T. canadensis cones and seeds running a distant second. Although seeds continually germinate from the seed bank, they are replenished by the seed rain, and species richness in the seed bank was similar before treatments were applied (in 2004; [93]) and five years after (in 2010; [94]). Nonetheless, the understory vegetationherbs, tree seedlings, and saplings-was not compositionally similar to the seed bank in the hemlock and hardwood control plots because seed germination is suppressed by the dense overstories in those plots. However, following canopy removals either by girdling or logging, the understory vegetation has become more similar to the seed bank as seeds germinated and seedlings established [94].

4.3. Vegetation. When HF-HeRE began, the hemlock plots were larger (had more basal area) than the young hardwood plots, and there was a bit more basal area in plots on the ridge than there was in the valley [92]. Four years after logging and girdling, these plots had lost nearly $70 \%$ of their basal area and more than $60 \%$ of their stems [19]. However, the pace and structure of loss differed between the two treatments. In the logged plots, basal area was lost immediately as trees were felled, boles were removed from the site, and the remaining dead wood was piled on the forest floor. In the girdled plots, trees died over two years and $>80 \%$ of the dead trees (and their wood) is still standing (in early 2014). During this same time interval, the control plots added a $4-6 \%$ basal area and lost $\approx 10 \%$ of their stems to normal mortality and stand thinning.

Suppressed, subcanopy B. lenta and A. rubrum trees responded with more rapid growth to removal of $T$. canadensis by logging or girdling than did existing canopy dominants (Pinus strobus L. and Quercus rubra L.). Similarly, saplings (stems $>1.3 \mathrm{~m}$ tall but $<5 \mathrm{~cm}$ diameter) and stump sprouts responded rapidly to canopy removal, and by 2011, there were dense thickets of $B$. lenta in both the girdled and the logged plots [19].

The number of herbs and shrubs in the understory has been constant in both hemlock ( 8 species) and hardwood (20 species) control plots since 2003. In 2003, the logged and girdled plots had similarly low numbers of understory species, but by 2010, the species richness of the understory in these canopy-removal plots had increased by $50 \%[19$, 94]. Many new species in the manipulated plots were early successional opportunists and species with long-lived seed banks, including Aralia hispida Vent., Erechtites hieracifolia Raf., Rubus spp., Lysimachia quadrifolia L., and Dennstaedtia punctilobula (Michx.) T. Moore [94]. Two invasive species also had colonized the girdled plots by 2007: Berberis thunbergii DC. and Celastrus orbiculatus Thunb. (A. A. Barker Plotkin and A. M. Ellison, unpublished data).

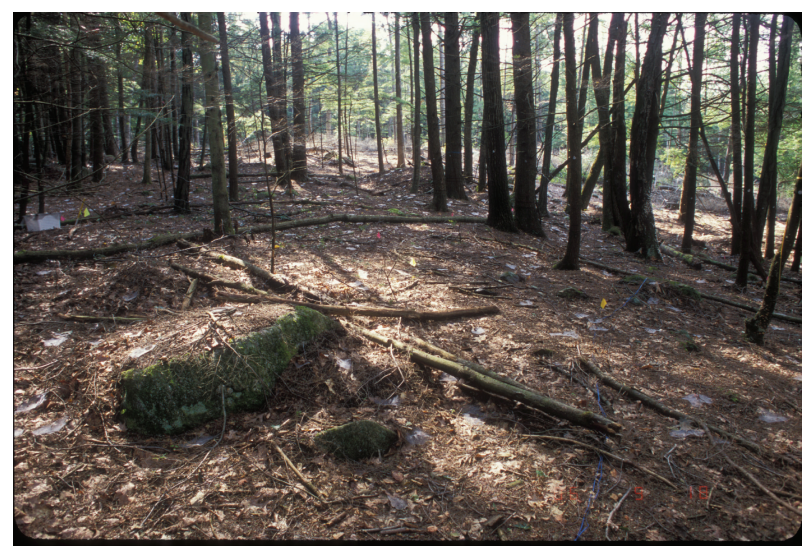

FIGURE 4: Webs of Agelenopsis spiders on the forest floor of a plot in which all T. canadensis individuals were girdled to kill them in place. The average web density $>5 / \mathrm{m}^{2}$. Photograph by the author.

4.4. Fauna. The most comprehensive data on faunal responses to loss of T. canadensis has come from annual samples of ants in the experimental plots. In parallel with observational data [7], we observed rapid colonization into the girdled and logged plots of large ants-notably Camponotus and Formica species-that are uncommon or absent in the hemlock control plots [12]. Species that favor open habitats, such as Formica dolosa Buren, have been collected only in the logged plots. The nearest other known occurrence of this species in the region is approximately $20 \mathrm{~km}$ north [97].

We have also sampled beetles and spiders, although not as regularly as ants. The predatory tiger beetle (Cicindela sexguttata Fabricius) has colonized the logged plots, while in the girdled plots, populations of web-building spiders have increased dramatically (Figure 4 ). In both girdled and logged plots, we hypothesize-as illustrated in Figure 3that as $T$. canadensis dies, top-down effects of predators will replace bottom-up effects of detritus as the dominant force controlling the dynamics of soil food webs.

In contrast, red-backed salamanders (Plethodon cinereus (Green)) and red-spotted newts (Notophthalmus viridescens (Raf.)) were more abundant in intact hemlock forests than in hardwood forests [9]. This premanipulation census is currently being replicated in the (posttreatment) canopymanipulation plots (A. A. Hassabelkreem, unpublished data).

The adelgid itself was first observed in the HF-HeRE plots at low densities in 2008. Infestation levels were assessed in the canopy-manipulation plots and controls in late summer and early fall, 2009. By then, $46 \%$ of the T. canadensis stems (trees, saplings, and seedlings) in the hemlock control plots, $20 \%$ of the T. canadensis stems in the hardwood controls, and $15 \%$ of the few small $T$. canadensis seedlings and saplings left in the logged plots were considered infested by the adelgid (A. A. Barker Plotkin and A. M. Ellison, unpublished data). We note that these numbers likely underestimate the infestation because the trees were surveyed in the summer, when the presence of adelgid is less obvious than at times when the white woolly is more visible. The adelgid was present in the logged and hardwood plots, but at much lower infestation 
rates. The few surviving T. canadensis individuals (mostly seedlings) in the girdled plots were not yet infested in 2009. The next adelgid census in the plots is scheduled for summer 2014.

4.5. Ecosystem Dynamics. If $T$. canadensis is functioning as a foundation species, then its loss also should lead to change in core ecosystem processes such as carbon flux and nutrient cycles. This prediction was supported most clearly for changes in litterfall, which is one index of aboveground primary productivity [98]. In the girdled treatment plots at HF-HeRE, there was a sharp pulse in litterfall followed by a gradual decline [19]; similar patterns have been observed in other hemlock girdling experiments [22, 39, 99]. This shift reflects only the transient loss of standing biomass as the canopy died; litterfall recovered within four years to premanipulation (i.e., control-plot) levels as understory shrubs (primarily Rubus spp.) and seedlings of Betula spp. rapidly colonized the girdled plots through seedling recruitment [94]. Not surprisingly, litterfall immediately decreased in the logged plots because trees were cut and removed from the site. Recovery of litterfall rates and quantities was slower in the logged plots than in the girdled plots because the soil scarification caused by and the residual material left on site from the logging operation $(\approx 1 \mathrm{~m}$ of coarse woody debris scattered throughout the plot) slowed colonization of the plots by other species [19]. However, hardwoods cut or damaged during the logging operation resprouted, contributing to local hot-spots of litterfall.

Among canopy-manipulation treatments, differences in productivity (i.e., litterfall) were pronounced. In contrast, carbon flux (i.e., soil respiration), nitrogen availability, and nitrogen cycling did not differ significantly among treatments because of high within-treatment variation. Rather, initial changes in energy and nutrient flux following canopy manipulations were modest and transient [19]. The rapid return to pretreatment levels of nitrogen availability reflected rapid establishment of other plant species following logging (e.g., [41, 95, 99, 100]); this has been observed in stands shortly following adelgid infestation [24, 26]. However, we also found no substantive differences in nitrogen mineralization between the hemlock and hardwood control plots, which may also reflect the generally nutrient-poor, glacially derived granitic soils at Harvard Forest. It is important to note, however, that changes in soil dynamics resulting from canopy change may take decades to centuries to appear. This is because a dominant driver of soil dynamics is the decomposition of large fallen boles and other coarse woody debris. In stands dominated by T. canadensis, decomposition is dominated by brown-rot fungi that primarily break down cellulose. In contrast, in hardwooddominated stands, decomposition is dominated by white-rot fungi that primarily break down lignin $[101,102]$. Thus, we hypothesize that over several centuries, soil nutrient availability in stands formerly dominated by $T$. canadensis will decline significantly only after dead $T$. canadensis boles and smaller coarse woody debris of $T$. canadensis branches and twigs have decomposed and brown-rot fungi are no longer dominant.

\section{Conclusion: Is Tsuga canadensis a Foundation Species?}

Observational, experimental, and modeling work of the role of T. canadensis in eastern North American forests provides one of the best opportunities to test the hypothesis that a single species of tree is a foundation species. Although the distribution and abundance of $T$. canadensis has expanded and contracted since the end of the most recent glaciation (ca. 15,000 years ago), when T. canadensis recovers and regains its local dominance, hemlock forests are like no other forest types in the region [27]. "Natural" or experimental removal of T. canadensis leads to immediate and long-term changes in the distribution and abundance of associated plant and animal species, and these are much more pronounced than when nearby hardwood forests are thinned, logged, or undergo succession. On the other hand, shifts in energy flux and biogeochemical cycles following loss of $T$. canadensis are expressed weakly in the short term; much longer-term experiments may reveal the extent to which $T$. canadensis and its microbial associates control ecosystem processes in hemlock stands.

I emphasize that most hemlock stands on the modernday landscape, and virtually all of the ones in which the role of T. canadensis as a foundation species has been studied, are relatively young (80-200-year-old) second-growth stands. The few remaining old-growth hemlock stands have very different characteristics from second-growth stands [103, 104], and the effects of the adelgid or logging on forest dynamics in such old-growth stands have not been studied. In addition, our interpretations of causes and consequences of changes in distribution and abundance of $T$. canadensis are conditioned on a particular set of historical events that have occurred in the region (e.g., $[3,53,96])$. From a vantage point in 2014 and in light of the loss of Castanea dentata from North American forests in the early twentieth century; ongoing declines of many other forest tree species, including Fagus grandifolia Ehrh. and Acer saccharum Marsh; land clearance by European colonists from the 1600s through the mid-19th century; continued logging of P. strobus, Quercus alba L., Q. rubra, and Carya spp. from our forests; and the extirpation of many top predators, Tsuga canadensis appears to be a foundation species. The permanence of this foundation, however, remains an open avenue for research.

\section{Conflict of Interests}

The author declares that there is no conflict of interests regarding the publication of this paper.

\section{Acknowledgments}

The research summarized here is the product of many years of sustained effort and field work by dozens of senior scientists, graduate students and postdocs, research assistants, and undergraduates; they are all gratefully acknowledged here and by name in the many publications cited below. All of the raw data generated from Harvard Forest 
research, including the studies described herein, are freely available through the online Harvard Forest Data Archive, http://harvardforest.fas.harvard.edu/data-archive. Observational and experimental work on hemlock and its decline has been supported financially by the Harvard Forest; by the US National Science Foundation through its programs in Long Term Ecological Research (DEB 0080592, 0620443, and 1237491), Ecosystems Research (DEB 0236897), and Research Experiences for Undergraduates (DBI 0452254 and 1003938); and by the US Department of Energy's Office of Science through its Northeast Regional Center of the National Institute for Global Environmental Change under cooperative Agreement no. DE-FC02-03ER63613.

\section{References}

[1] P. K. Dayton, "Toward an understanding of community resilience and the potential effects of enrichments to the benthos at McMurdo Sound, Antarctica," in Proceedings of the Colloquium on Conservation Problems in Antarctica, B. C. Parker, Ed., pp. 81-95, Allen Press, Lawrence, Kan, USA, 1972.

[2] A. M. Ellison, M. S. Bank, B. D. Clinton et al., "Loss of foundation species: consequences for the structure and dynamics of forested ecosystems," Frontiers in Ecology and the Environment, vol. 3, no. 9, pp. 479-486, 2005.

[3] D. R. Foster, Hemlock: A Forest Giant on the Edge, Yale University Press, New Haven, Conn, USA, 2014.

[4] R. S. Rogers, "Hemlock stands from Wisconsin to Nova Scotia: transitions in understory composition along a floristic gradient," Ecology, vol. 61, pp. 178-193, 1980.

[5] W. B. Smith, P. D. Miles, C. H. Perry, and S. A. Pugh, "Forest resources of the United States, 2007," USDA/USFS Gen Tech Rep WO-78, 2009.

[6] M. W. Tingley, D. A. Orwig, R. Field, and G. Motzkin, "Avian response to removal of a forest dominant: consequences of hemlock woolly adelgid infestations," Journal of Biogeography, vol. 29, no. 10-11, pp. 1505-1516, 2002.

[7] A. M. Ellison, J. Chen, D. Díaz, C. Kammerer-Burnham, and M. Lau, "Changes in ant community structure and composition associated with hemlock decline in New England," in Proceedings of the 3rd Symposium on Hemlock Woolly Adelgid in the Eastern United States, B. Onken and R. Reardon, Eds., pp. 280289, USDA/USFS: Forest Health Technology Enterprise Team, Morgantown, WVa, USA, 2005.

[8] C. Dilling, P. Lambdin, J. Grant, and L. Buck, "Insect guild structure associated with eastern hemlock in the Southern Appalachians," Environmental Entomology, vol. 36, no. 6, pp. 1408-1414, 2007.

[9] B. Mathewson, "The relative abundance of Eastern red-backed Salamander in Eastern Hemlock-dominated and mixed deciduous forests at Harvard Forest," Northeastern Naturalist, vol. 16, no. 1, pp. 1-12, 2009.

[10] J. R. Rohr, C. G. Mahan, and K. C. Kim, "Response of arthropod biodiversity to foundation species declines: the case of the eastern hemlock," Forest Ecology and Management, vol. 258, no. 7, pp. 1503-1510, 2009.

[11] R. E. Mallis and L. K. Rieske, "Arboreal spiders in eastern hemlock," Environmental Entomology, vol. 40, no. 6, pp. 13781387, 2011.

[12] T. E. Sackett, S. Record, S. Bewick, B. Baiser, N. J. Sanders, and A. M. Ellison, "Response of macroarthropod assemblages to the loss of hemlock (Tsuga canadensis), a foundation species," Ecosphere, vol. 2, article 74, 2011.

[13] C. D. Snyder, J. A. Young, D. P. Lemarié, and D. R. Smith, "Influence of eastern hemlock (Tsuga canadensis) forests on aquatic invertebrate assemblages in headwater streams," Canadian Journal of Fisheries and Aquatic Sciences, vol. 59, no. 2, pp. 262-275, 2002.

[14] L. A. Siderhurst, H. P. Griscom, M. Hudy, and Z. J. Bortolot, "Changes in light levels and stream temperatures with loss of eastern hemlock (Tsuga canadensis) at a southern Appalachian stream: implications for brook trout," Forest Ecology and Management, vol. 260, no. 10, pp. 1677-1688, 2010.

[15] M. N. Lustenhouwer, L. Nicoll, and A. M. Ellison, "Microclimatic effects of the loss of a foundation species from New England forest," Ecosphere, vol. 3, p. 26, 2012.

[16] J. L. Hadley, P. S. Kuzeja, M. J. Daley, N. G. Phillips, T. Mulcahy, and S. Singh, "Water use and carbon exchange of red oakAnd eastern hemlock-dominated forests in the northeastern USA: implications for ecosystem-level effects of hemlock woolly adelgid," Tree Physiology, vol. 28, no. 4, pp. 615-627, 2008.

[17] R. C. Cobb, D. A. Orwig, and S. Currie, "Decomposition of green foliage in eastern hemlock forests of southern New England impacted by hemlock woolly adelgid infestations," Canadian Journal of Forest Research, vol. 36, no. 5, pp. 1331-1341, 2006.

[18] J. D. Aber and J. M. Melillo, Terrestrial Eecosystems, Saunders College, Philadelphia, Pa, USA, 1991.

[19] D. A. Orwig, A. A. B. Plotkin, E. A. Davidson, H. Lux, K. E. Savage, and A. M. Ellison, "Foundation species loss affects vegetation structure more than ecosystemfunction in a northeastern USA forest," PeerJ, vol. 2013, no. 1, article e41, 2013.

[20] K. E. Savage and E. A. Davidson, "Interannual variation of soil respiration in two New England forests," Global Biogeochemical Cycles, vol. 15, no. 2, pp. 337-350, 2001.

[21] G. M. Lovett, C. D. Canham, M. A. Arthur, K. C. Weathers, and R. D. Fitzhugh, "Forest ecosystem responses to exotic pests and pathogens in eastern North America," BioScience, vol. 56, no. 5, pp. 395-405, 2006.

[22] A. E. Nuckolls, N. Wurzburger, C. R. Ford, R. L. Hendrick, J. M. Vose, and B. D. Kloeppel, "Hemlock declines rapidly with hemlock woolly adelgid infestation: impacts on the carbon cycle of southern Appalachian forests," Ecosystems, vol. 12, no. 2, pp. 179-190, 2009.

[23] C. R. Ford, K. J. Elliott, B. D. Clinton, B. D. Kloeppel, and J. M. Vose, "Forest dynamics following eastern hemlock mortality in the southern Appalachians," Oikos, vol. 121, no. 4, pp. 523-536, 2012.

[24] J. C. Jenkins, J. D. Aber, and C. D. Canham, "Hemlock woolly adelgid impacts on community structure and $\mathrm{N}$ cycling rates in eastern hemlock forests," Canadian Journal of Forest Research, vol. 29, no. 5, pp. 630-645, 1999.

[25] B. Stadler, T. Müller, D. Orwig, and R. Cobb, "Hemlock woolly adelgid in New England forests: canopy impacts transforming ecosystem processes and landscapes," Ecosystems, vol. 8, no. 3, pp. 233-247, 2005.

[26] D. A. Orwig, R. C. Cobb, A. W. D’Amato, M. L. Kizlinski, and D. R. Foster, "Multi-year ecosystem response to hemlock woolly adelgid infestation in southern New England forests," Canadian Journal of Forest Research, vol. 38, no. 4, pp. 834-843, 2008.

[27] A. M. Ellison, "Reprise: eastern hemlock as a foundation species," in Hemlock: A Forest Giant on the Edge, D. R. Foster, 
Ed., pp. 165-171, Yale University Press, New Haven, Conn, USA, 2014.

[28] A. M. Ellison and B. Baiser, "Hemlock as a foundation species," in Hemlock: A Forest Giant on the Edge, D. R. Foster, Ed., pp. 93-104, Yale University Press, New Haven, Conn, USA, 2014.

[29] A. M. Ellison, D. A. Orwig, and A. A. Barker Plotkin, "Cut or girdle," in Hemlock: A Forest Giant on the Edge, D. R. Foster, Ed., pp. 136-152, Yale University Press, New Haven, Conn, USA, 2014.

[30] H. P. Havill, M. E. Montgomery, G. Y. Yu, S. Shiyake, and A. Caccone, "Mitochondrial DNA from hemlock woolly adelgid (Hemiptera: Adelgidae) suggests cryptic speciation and pinpoints the source of the introduction to eastern North America," Annals of the Entomological Society of America, vol. 99, no. 2, pp. 195-203, 2006.

[31] R. S. Morin, A. M. Liebhold, and K. W. Gottschalk, "Anisotropic spread of hemlock woolly adelgid in the eastern United States," Biological Invasions, vol. 11, no. 10, pp. 2341-2350, 2009.

[32] M. C. Fitzpatrick, E. L. Preisser, A. Porter et al., "Ecological boundary detection using Bayesian areal wombling," Ecology, vol. 91, no. 12, pp. 3448-3455, 2010.

[33] M. C. Fitzpatrick, E. L. Preisser, A. Porter, J. Elkinton, and A. M. Ellison, "Modeling range dynamics in heterogeneous landscapes: invasion of the hemlock woolly adelgid in eastern North America," Ecological Applications, vol. 22, no. 2, pp. 472486, 2012.

[34] L. L. Ingwell and E. L. Preisser, "Using citizen science programs to identify host resistance in pest-invaded forests," Conservation Biology, vol. 25, no. 1, pp. 182-188, 2011.

[35] M. S. McClure, "Managing hemlock woolly adelgid in ornamental landscapes," Bulletin/Connecticut Agricultural Experiment Station, vol. 925, 1995.

[36] D. A. Orwig, J. Thompson, N. A. Povak, M. Manner, D. Niebyl, and D. R. Foster, "A foundation tree at the precipice: eastern hemlock health following the arrival of Adelges tsugae in central New England," Ecosphere, vol. 3, p. 10, 2012.

[37] D. A. Orwig, D. R. Foster, and D. L. Mausel, "Landscape patterns of hemlock decline in New England due to the introduced hemlock woolly adelgid," Journal of Biogeography, vol. 29, no. 10-11, pp. 1475-1487, 2002.

[38] A. K. Eschtruth, N. L. Cleavitt, J. J. Battles, R. A. Evans, and T. J. Fahey, "Vegetation dynamics in declining eastern hemlock stands: 9 years of forest response to hemlock woolly adelgid infestation," Canadian Journal of Forest Research, vol. 36, no. 6, pp. 1435-1450, 2006.

[39] J. D. Knoepp, J. M. Vose, B. D. Clinton, and M. D. Hunter, "Hemlock infestation and mortality: impacts on nutrient pools and cycling in appalachian forests," Soil Science Society of America Journal, vol. 75, no. 5, pp. 1935-1945, 2011.

[40] M. S. McClure, "Density-dependent feedback and population cycles in Adelges tsugae (Homoptera: Adelgidae) on Tsuga canadensis," Environmental Entomology, vol. 20, pp. 258-264, 1991.

[41] M. L. Kizlinski, D. A. Orwig, R. C. Cobb, and D. R. Foster, "Direct and indirect ecosystem consequences of an invasive pest on forests dominated by eastern hemlock," Journal of Biogeography, vol. 29, no. 10-11, pp. 1489-1503, 2002.

[42] R. T. Brooks, "Early regeneration following the presalvage cutting of hemlock from hemlock-dominated stands," Northern Journal of Applied Forestry, vol. 21, no. 1, pp. 12-18, 2004.
[43] D. A. Orwig and D. R. Foster, "Forest response to the introduced hemlock woolly adelgid in Southern New England, USA," The Journal of the Torrey Botanical Society, vol. 125, no. 1, pp. 60-73, 1998.

[44] M. Albani, P. R. Moorcroft, A. M. Ellison, D. A. Orwig, and D. R. Foster, "Predicting the impact of hemlock woolly adelgid on carbon dynamics of eastern United States forests," Canadian Journal of Forest Research, vol. 40, no. 1, pp. 119-133, 2010.

[45] P. C. L. Raymer, D. A. Orwig, and A. C. Finzi, "Hemlock loss due to the hemlock woolly adelgid does not affect ecosystem C storage but alters its distribution," Ecosphere, vol. 4, article 63, 2013.

[46] B. L. Parker, M. Skinner, S. Gouli, T. Ashikaga, and H. B. Teillon, "Survival of hemlock woolly adelgid (Homoptera: Adelgidae) at low temperatures," Forest Science, vol. 44, no. 3, pp. 414-420, 1998.

[47] B. L. Parker, M. Skinner, S. Gouli, T. Ashikaga, and H. B. Teillon, "Low lethal temperature for hemlock woolly adelgid (Homoptera: Adelgidae)," Environmental Entomology, vol. 28, no. 6, pp. 1085-1091, 1999.

[48] M. Skinner, B. L. Parker, S. Gouli, and T. Ashikaga, "Regional responses of hemlock woolly adelgid (Homoptera: Adelgidae) to low temperatures," Environmental Entomology, vol. 32, no. 3, pp. 523-528, 2003.

[49] A. Paradis, J. Elkinton, K. Hayhoe, and J. Buonaccorsi, "Role of winter temperature and climate change on the survival and future range expansion of the hemlock woolly adelgid (Adelges tsugae) in eastern North America," Mitigation and Adaptation Strategies for Global Change, vol. 13, no. 5-6, pp. 541-554, 2008.

[50] R. T. Trotter and K. S. Shields, "Variation in winter survival of the invasive hemlock woolly adelgid (Hemiptera: Adelgidae) across the eastern United States," Environmental Entomology, vol. 38, no. 3, pp. 577-587, 2009.

[51] E. Boose, "Fisher Meteorological Station at Harvard Forest since 2001," Harvard Forest Data Archive HF001, 2001.

[52] M. A. Huston, Biological Diversity: The Coexistence of Species on Changing Landscapes, Cambridge University Press, New York, NY, USA, 1994.

[53] D. R. Foster and T. M. Zebryk, "Long-term vegetation dynamics and disturbance history of a Tsuga- dominated forest in New England," Ecology, vol. 74, no. 4, pp. 982-998, 1993.

[54] J. S. McLachlan, D. R. Foster, and F. Menalled, "Anthropogenic ties to late-successional structure and composition in four New England hemlock stands," Ecology, vol. 81, no. 3, pp. 717-733, 2000.

[55] D. R. Foster, W. W. Oswald, E. K. Faison, E. D. Doughty, and B. C. S. Hansen, "A climatic driver for abrupt mid-Holocene vegetation dynamics and the hemlock decline in New England," Ecology, vol. 87, no. 12, pp. 2959-2966, 2006.

[56] S. Record, M. C. Fitzpatrick, A. O. Finley, S. Veloz, and A. M. Ellison, "Should species distribution models account for spatial autocorrelation? A test of model projections across eight millennia of climate change," Global Ecology and Biogeography, vol. 22, no. 6, pp. 760-771, 2013.

[57] D. R. Foster and D. A. Orwig, "Preemptive and salvage harvesting of New England forests: when doing nothing is a viable alternative," Conservation Biology, vol. 20, no. 4, pp. 959-970, 2006.

[58] P. W. Rundel, E. A. Graham, M. F. Allen, J. C. Fisher, and T. C. Harmon, "Environmental sensor networks in ecological research," New Phytologist, vol. 182, no. 3, pp. 589-607, 2009. 
[59] R. H. Kao, C. M. Gibson, R. E. Gallery et al., "NEON terrestrial field observations: designing continental-scale, standardized sampling," Ecosphere, vol. 3, no. 12, article 115, 2012.

[60] H. Loescher, E. Ayres, P. Duffy, Y. Luo, and M. Brunke, "Spatial variation in soil properties among North American ecosystems and guidelines for sampling designs," PLoS ONE, vol. 9, no. 1, Article ID e83216, 2014.

[61] T. C. Chamberlin, "The method of multiple working hypotheses," Science, vol. 15, pp. 92-96, 1890.

[62] K. R. Popper, The Logic of Scientific Discovery, Routledge, London, UK, 1959.

[63] J. R. Platt, "Strong inference," Science, vol. 146, no. 3642, pp. 347353, 1964.

[64] A. J. Underwood, Experiments in Ecology: Their Logical Design and Interpretation Using Analysis of Variance, Cambridge University Press, Cambridge, Mass, USA, 1997.

[65] N. J. Gotelli and A. M. Ellison, A Primer of Ecological Statistics, Sinauer, Sunderland, UK, 2nd edition, 2012.

[66] A. Stewart-Oaten, W. W. Murdoch, and K. R. Parker, "Environmental impact assessment: "pseudoreplication" in time?" Ecology, vol. 67, no. 4, pp. 929-940, 1986.

[67] A. Stewart-Oaten, J. R. Bence, and C. W. Osenberg, "Assessing effects of unreplicated perturbations: no simple solutions," Ecology, vol. 73, no. 4, pp. 1396-1404, 1992.

[68] R. T. Paine, "Food web complexity and species diversity," The American Naturalist, vol. 100, pp. 65-75, 1966.

[69] I. Hanski, "Dynamics of regional distribution: the core and satellite species hypothesis," Oikos, vol. 38, pp. 210-221, 1982.

[70] D. Rabinowitz, "Seven forms of rarity," in The Biological Aspects of Rare Plant Conservation, H. Synge, Ed., pp. 205-217, Wiley, New York, NY, USA, 1981.

[71] B. J. McGill, R. S. Etienne, J. S. Gray et al., "Species abundance distributions: moving beyond single prediction theories to integration within an ecological framework," Ecology Letters, vol. 10, no. 10, pp. 995-1015, 2007.

[72] C. D. Collins, R. D. Holt, and B. L. Foster, "Patch size effects on plant species decline in an experimentally fragmented landscape," Ecology, vol. 90, no. 9, pp. 2577-2588, 2009.

[73] C. E. Zartman, H. E. M. Nascimento, K. G. Cangani, L. D. P. Alvarenga, and T. Snäll, "Fine-scale changes in connectivity affect the metapopulation dynamics of a bryophyte confined to ephemeral patches," Journal of Ecology, vol. 100, no. 4, pp. 980986, 2012.

[74] M. K. Borregaard and C. Rahbek, "Causality of the relationship between geographic distribution and species abundance," Quarterly Review of Biology, vol. 85, no. 1, pp. 3-25, 2010.

[75] J. P. Grime, "Dominant and subordinate components of plant communities: implications for succession, stability and diversity," in Colonization, Succession and Stability, A. J. Gray, M. J. Crawley, and P. J. Edwards, Eds., pp. 413-428, Blackwell, Oxford, UK, 1987.

[76] M. D. Smith and A. K. Knapp, "Dominant species maintain ecosystem function with non-random species loss," Ecology Letters, vol. 6, no. 6, pp. 509-517, 2003.

[77] M. D. Smith, J. C. Wilcox, T. Kelly, and A. K. Knapp, "Dominance not richness determines invasibility of tallgrass prairie," Oikos, vol. 106, no. 2, pp. 253-262, 2004.

[78] A. Hector, Y. Hautier, P. Saner et al., "General stabilizing effects of plant diversity on grassland productivity through population asynchrony and overyielding," Ecology, vol. 91, no. 8, pp. 22132220, 2010.
[79] K. J. Gaston and R. A. Fuller, "Commonness, population depletion and conservation biology," Trends in Ecology and Evolution, vol. 23, no. 1, pp. 14-19, 2008.

[80] C. S. Holling, "Cross-scale morphology, geometry, and dynamics of ecosystems," Ecological Monographs, vol. 62, no. 4, pp. 447-502, 1992.

[81] P. K. Dayton, G. A. Robilliard, R. T. Paine, and L. B. Dayton, "Biological accommodation in the benthic community at McMurdo Sound, Antarctica," Ecological Monographs, vol. 44, no. 1, pp. 105-128, 1974.

[82] C. G. Jones, J. H. Lawton, and M. Shachak, "Organisms as ecosystem engineers," Oikos, vol. 69, no. 3, pp. 373-386, 1994.

[83] F. J. Odling-Smee, K. N. Laland, and M. W. Feldman, Niche Construction: The Neglected Process in Evolution, Princeton University Press, Princeton, NJ, USA, 2003.

[84] M. E. S. Bracken and N. H. N. Low, "Realistic losses of rare species disproportionately impact higher trophic levels," Ecology Letters, vol. 15, no. 5, pp. 461-467, 2012.

[85] A. C. Redfield, "Development of a New England salt marsh," Ecological Monographs, vol. 42, pp. 201-237, 1972.

[86] M. D. Bertness and S. D. Hacker, "Physical stress and positive associations among marsh plants," The American Naturalist, vol. 144, no. 3, pp. 363-372, 1994.

[87] J. F. Bruno, "Facilitation of cobble beach plant communities through habitat modification by Spartina alterniflora," Ecology, vol. 81, no. 5, pp. 1179-1192, 2000.

[88] J. B. Van Hulzen, J. Van Soelen, and T. J. Bouma, "Morphological variation and habitat modification are strongly correlated for the autogenic ecosystem engineer Spartina anglica (Common Cordgrass)," Estuaries and Coasts, vol. 30, no. 1, pp. 3-11, 2007.

[89] J. A. Crooks, "Characterizing ecosystem-level consequences of biological invasions: the role of ecosystem engineers," Oikos, vol. 97, no. 2, pp. 153-166, 2002.

[90] D. E. Pearson, "Trait-and density-mediated indirect interactions initiated by an exotic invasive plant autogenic ecosystem engineer," American Naturalist, vol. 176, no. 4, pp. 394-403, 2010.

[91] B. Baiser, N. Whitaker, and A. M. Ellison, "Modeling foundation species in food webs," Ecosphere, vol. 4, p. 146, 2013.

[92] A. M. Ellison, A. A. Barker-Plotkin, D. R. Foster, and D. A. Orwig, "Experimentally testing the role of foundation species in forests: the Harvard forest hemlock removal experiment," Methods in Ecology and Evolution, vol. 1, no. 2, pp. 168-179, 2010.

[93] K. A. Sullivan and A. M. Ellison, “The seed bank of hemlock forests: implications for forest regeneration following hemlock decline," Journal of the Torrey Botanical Society, vol. 133, no. 3, pp. 393-402, 2006.

[94] E. J. Farnsworth, A. A. B. Plotkin, and A. M. Ellison, "The relative contributions of seed bank, seed rain, and understory vegetation dynamics to the reorganization of Tsuga canadensis forests after loss due to logging or simulated attack by Adelges tsugae," Canadian Journal of Forest Research, vol. 42, no. 12, pp. 2090-2105, 2012.

[95] P. H. Templer and T. M. McCann, "Effects of the hemlock woolly adelgid on nitrogen losses from urban and rural northern forest ecosystems," Ecosystems, vol. 13, no. 8, pp. 1215-1226, 2010.

[96] A. M. Ellison, M. Lavine, P. B. Kerson, and A. A. Barker Plotkin, "Building a foundation: land-use history and dendrochronology reveal temporal dynamics of a Tsuga canadensis (Pinaceae) forest," Rhodora. In press. 
[97] A. M. Ellison, N. J. Gotelli, E. J. Farnsworth, and G. D. Alpert, A Field Guide to the Ants of New England, Yale University Press, New Haven, Conn, USA, 2012.

[98] D. Zheng, S. Prince, and T. Hame, "Estimating net primary production of boreal forests in Finland and Sweden from field data and remote sensing," Journal of Vegetation Science, vol. 15, no. 2, pp. 161-170, 2004.

[99] T. E. Yorks, D. J. Leopold, and D. J. Raynal, "Effects of Tsuga canadensis mortality on soil water chemistry and understory vegetation: possible consequences of an invasive insect herbivore," Canadian Journal of Forest Research, vol. 33, no. 8, pp. 1525-1537, 2003.

[100] L. E. Nave, C. M. Gough, K. D. Maurer et al., "Disturbance and the resilience of coupled carbon and nitrogen cycling in a north temperate forest," Journal of Geophysical Research G: Biogeosciences, vol. 116, no. 4, Article ID G04016, 2011.

[101] A. Hatakka, "Biodegradation of lignin," in Biopolymers. Biology, Chemistry, Biotechnology, Applications. Volume 1. Lignin, Humic Substances and Coal, M. Hofrichter and A. Steinbüchel, Eds., pp. 129-180, Wiley-VCH, Weinheim, Germany, 2001.

[102] D. Floudas, M. Binder, R. Riley et al., "The paleozoic origin of enzymatic lignin decomposition reconstructed from 31 fungal genomes," Science, vol. 336, no. 6089, pp. 1715-1719, 2012.

[103] C. G. Lorimer, "Dynamics and structural characteristics of eastern hemlock stands," in Proceedings of the Conference on Hemlock Ecology and Management, G. Mroz and A. J. Martin, Eds., pp. 43-59, Department of Forestry, University of WisconsinMadison, Madison, Wis, USA, 1995.

[104] M. B. Davis, Eastern Old-Growth Forests: Prospects for Rediscovery and Recovery, Island Press, Washington, Wash, USA, 1996. 

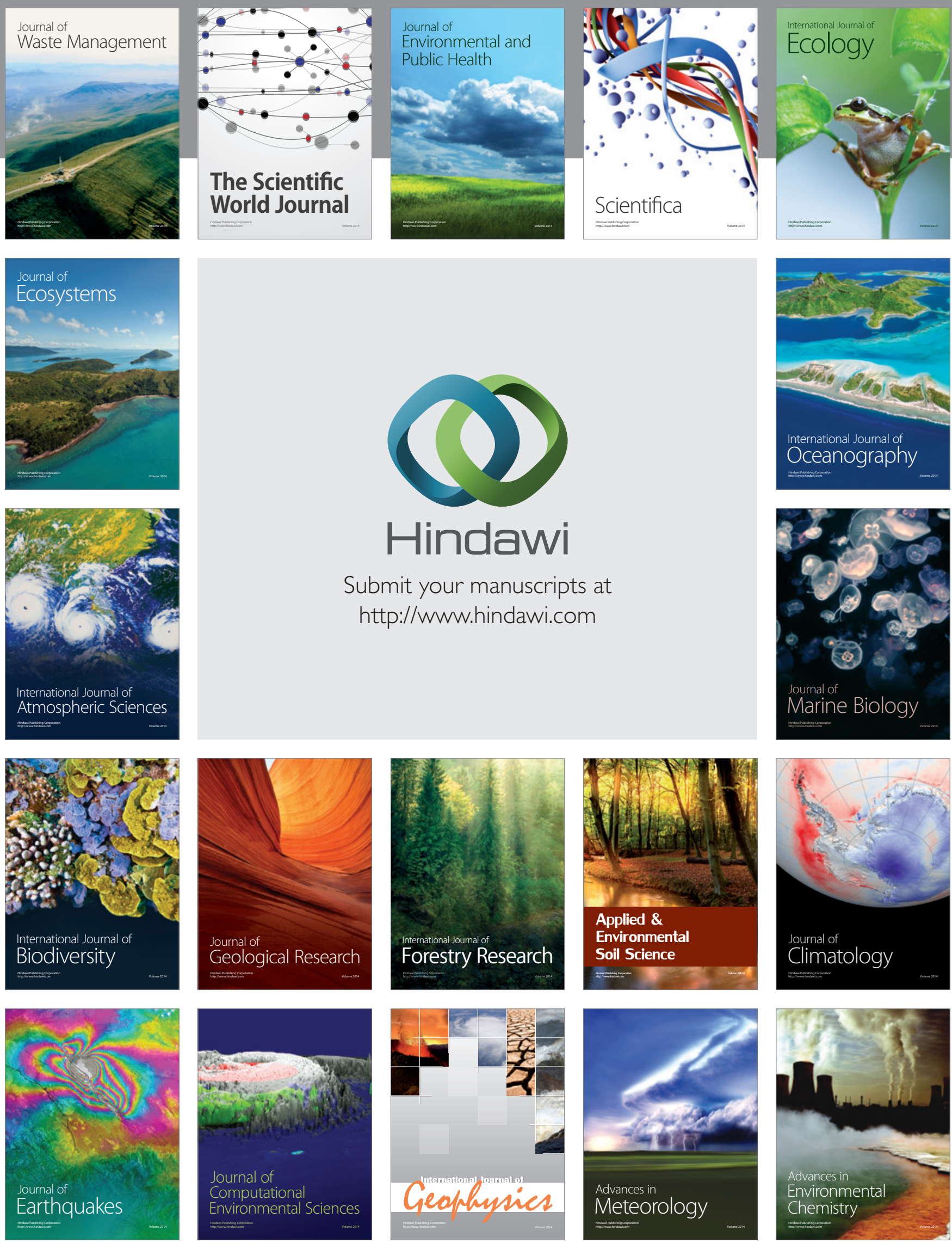